EDITORIAL

\title{
Public health and the power of individual action
}

\author{
J B Richmond, D M Burns, K M Cummings
}

Tobacco Control 2004;13(Suppl I):i1-i2. doi: 10.1136/tc.2004.007450

D ramatic changes in smoking behaviour occurred over the half century since cigarette smoking was identified as a cause of human disease, and these changes are a major public health accomplishment. ${ }^{1}$ Perhaps no component of this change has been more dramatic than the reduction in people's involuntary exposure to tobacco smoke pollution. The fraction of indoor workers protected by a total ban on smoking in the workplace has risen from $3 \%$ in $1986^{2}$ to nearly $70 \%$ in $1999,{ }^{3}$ and serum cotinine levels in non-smokers declined 70\% between 1988 and 1998. ${ }^{4}$ Much of this progress can be attributed to the courageous and determined actions of individuals applying our advances in the medical sciences. This issue both celebrates those individuals and details their accomplishments.

Almost immediately following Surgeon General Jesse Steinfeld's articulation of involuntary smoking as a public health issue and his declaration of a non-smokers bill of rights, ${ }^{5}$ airlines became the leading edge of a societal change that would de-normalise smoking and protect non-smokers from exposure to tobacco smoke. As presented by Holm and Davis ${ }^{6}$ in this issue, aircraft were one of the first public places to have separate smoking and non-smoking sections, and regulation of airline travel would continue to lead the rest of society toward banning smoking in the work environment for the next two decades. Efforts to regulate exposure to tobacco smoke in air travel culminated in the elimination of all smoking on domestic flights lasting less than two hours in 1988, a total ban on domestic flights in 1990, and a ban on international flights in 2000 .

Progress on airplanes was a highly visible example for the rest of society, and the experience by the flying public deserves credit for legitimising demands for separate sections in the early years and for a complete ban in later years. This progress did not occur spontaneously or without enormous effort on the part of many individuals and organisations. However, two groups deserve to be singled out for their contributions: flight attendants and lawyers.

authe of article for authors' affiliations

Correspondence to: K Michael Cummings, $\mathrm{PhD}, \mathrm{MPH}$, Department of Health Behavior, Division of Cancer Prevention \& Population Sciences, Roswell Park Cancer Institute, Elm and Carlton Streets, Buffalo, New York 14263, USA Michael.Cummings@ roswellpark.org volume. ${ }^{7}$ They were truly the "canaries in the coal mines", and like the canaries they often suffered serious illnesses or died as a consequence of their exposures. Indeed, as Holm and Davis $^{6}$ describe, it was the reports of the exposures of flight attendants compellingly presented to Congress, as well as their determined advocacy on this issue, that finally led Congress to ban smoking on commercial aircraft. This groundbreaking legislation would not have been possible without the courageous and persistent efforts of this small group of individuals.

Equally persistent were the few dedicated legal advocates willing to take on this issue and who struggled to create regulatory protections and to fight for the rights of those injured or at risk. They faced the dual burdens of creating law where none previously existed and fighting the tobacco industry which correctly perceived this issue as one critical to its survival. The challenges and heartaches of this long and often frustrating process of building a body of law and precedent is carefully laid out by Sweda ${ }^{8}$ in this issue, and it is abundantly clear the debt that we nonsmokers owe to this small but persistent band of attorneys.

\section{TOBACCO INDUSTRY OPPOSITION}

The tobacco industry has and continues to devote its enormous resources and political leverage in opposition to protections in the workplace, restrictions in public places, litigation to recover damages for injured non-smokers, and most particularly protection for flight attendants on aircraft. The tobacco companies correctly recognised that issues raised by exposure to secondhand smoke were both ones of disease risks and of social acceptability of their products. Without social acceptability, the hold that cigarettes had on the addicted smoker was lessened, and many would quit. Indeed, the tobacco industry's own internal documents reveal the dramatic effect restricting smoking in the workplace has on reducing smoking consumption and increasing cessation. ${ }^{9}$ This was an issue likely to severely reduce tobacco company profits, and they fought with every tool at their disposal.

While it should come as no surprise now that 50 years of industry misconduct have been revealed through the disclosure of their internal documents, ${ }^{10}$ the tobacco companies conducted a brazen effort to distort and misrepresent science in an effort to influence public policy on environmental tobacco smoke. Three examples of this effort to distort science are presented in this issue. Neilsen and Glantz ${ }^{11}$ describe the manipulation of the evidence from a study of airline air quality in order to mislead policymakers about 
the severity of the problem and the potential solutions. Drope and colleagues ${ }^{12}$ document a sustained effort by the industry to recruit a group of individuals who could be presented as "independent experts" when issues related to secondhand smoke were being considered, and to specifically promote the false premise that increased ventilation was the optimal solution for reducing non-smokers exposure to tobacco smoke pollution. Pion and Givel ${ }^{13}$ recount a specific example of tobacco industry opposition and distortion of the scientific evidence. They document an effort to sidetrack the protection of non-smokers in the Lambert-St Louis airport through the use of smoking rooms. These authors go on to demonstrate that smoking rooms do not eliminate exposure to nonsmokers. The breadth and extent of tobacco company opposition, and their willingness to break all of the rules, brings into sharp focus the courage and determination of the flight attendants and lawyers who have led the way in protecting the rest of society.

\section{SCIENTIFIC EVIDENCE}

The scientific evidence establishing secondhand smoke exposure as a cause of disease has been clearly documented in other reviews. ${ }^{14-16}$ This issue continues to expand that body of evidence by presenting newer methods for measuring exposure to the specific toxic and carcinogenic constituents present in environmental tobacco smoke (ETS) ${ }^{17}$ and by detailing the evidence linking exposure to ETS and development of nasal and sinus irritation, inflammation, and chronic sinusitis. ${ }^{18}$

In the foreword to this issue, law Professor Richard Daynard presents his perspective on our current level of success $^{19}$ in defending the right of non-smokers to breath air free of tobacco smoke. Daynard observes that no case has had more impact than the class action lawsuit brought by Stanley and Susan Rosenblatt on behalf of non-smoking flight attendants. It is uniquely appropriate that the signature legal case on environmental tobacco smoke injury would be brought on behalf of those same flight attendants who were pioneers in the effort to protect the rest of society from tobacco smoke pollution. For the first time the industry acknowledged defeat, four months into the trial, by offering $\$ 300$ million to set up the Flight Attendant Medical Research Institute (FAMRI).

It is also fitting that the greatest legal success was achieved by two individuals with the courage and vision to do what they believed to be right in the face of overwhelming advice suggesting that the task was impossible, given the imposing power and resources the tobacco companies would bring to bear. We need no better example of what committed individuals, armed with the truth, can accomplish for public health.

For many, the articles in this issue will awaken old memories; and for most, the articles will provide new information and insights that provide a roadmap for continuing efforts to protect the rights of non-smokers to smoke-free air. However, the most enduring lesson contained within this volume is the power of individual action. Over and over again in these pages we see the impact of courageous choices by committed individuals who often acted against self interest in an effort to promote and protect the public's health. It is the sum of those individual choices that has resulted in a remarkable public health triumph. It is also the example of those choices that stand as a challenge to all of us as we approach the future.

\section{Authors' affiliations}

J B Richmond, Chairman FAMRI Medical Advisory Board, John D MacArthur Professor of Health Policy, Emeritus, Department of Social Medicine, Harvard Medical School, Boston, Massachusetts, USA

D M Burns, Professor of Family and Preventive Medicine, University of California, San Diego School of Medicine, San Diego, California, USA K M Cummings, Chairman, Department of Health Behavior, Division of Cancer Prevention \& Population Sciences, Roswell Park Cancer Institute, Buffalo, New York, USA

\section{REFERENCES}

1 US Department of Health and Human Services. Reducing the health consequences of smoking: 25 years of progress. A report of the Surgeon General, 1989. Rockville, Maryland: Public Health Service, Centers for Disease Control, Office on Smoking and Health, 1989. (DHHS Publication No (CDC) 89-8411.)

2 Center for Disease Control. Passive smoking: beliefs, attitudes, and exposures - United States, 1986. MMWR Morb Mortal Wkly Rep 1988;37:239-41

3 Shopland DR, Gerlach KK, Burns DM, et al. State-specific trends in smoke-free workplace policy coverage. The current population survey tobacco use supplement, 1993 to 1999. J Occ Env Med 2001;43:680-6.

4 National Center for Environmental Health. Environmental tobacco smoke. 2nd National Report on Human Exposure to Environmental Chemicals. Atlanta, Georgia: Centers for Disease Control, National Center for Environmental Health, 2003.

5 Steinfeld JL. The public's responsibility: a bill of rights for the non-smoker. Rhode Island Med J 1972;55:124-6.

6 Holm AL, Davis RM. Clearing the airways: advocacy and regulation for smoke-free airlines. Tobacco Control 2004;13(suppl I):i30-6.

7 Repace JL. Flying the smoky skies: secondhand smoke exposure of flight attendants. Tobacco Control 2004;13(suppl I):i8-19.

8 Sweda EL Jr. Lawsuits and secondhand smoke. Tobacco Control 2004;13(suppl I):i61-6.

9 Heironimus J. Impact of workplace smoking restrictions on consumption and incidence. Philip Morris Inter-Office Memo dated 21 January 1992. Philip Morris Website www.pmdocs.com, Bates No. 2045447779.

10 UCSF Legacy Tobacco Documents Library. http://legacy.library.ucsf.edu/

11 Neilsen K, Glantz SA. A tobacco industry study of airline cabin air quality: dropping inconvenient findings. Tobacco Control 2004;13(suppl I):i20-9.

12 Drope J, Bialous SA, Glantz SA. Tobacco industry efforts to present ventilation as an alternative to smoke-free environments in North America. Tobacco Control 2004; 13(suppl I):i41-7.

13 Pion M, Givel MS. Airport smoking rooms don't work. Tobacco Control 2004; 13(suppl I):i37-40.

14 US Department of Health and Human Services. The health consequences of involuntary smoking. A report of the Surgeon General, 1986. Rockville, Maryland: Public Health Service, Centers for Disease Control, 1986. (DHHS Publication No (CDC) 87-8398.)

15 US Environmental Protection Agency. Respiratory health effects of passive smoking: lung cancer and other disorders. Washington, DC: Office of Health and Environmental Assessment, 1992. (Publication No EPA/600/6-90/ 006F.)

16 California Environmental Protection Agency, Office of Environmental Health Hazard Assessment. Health effects of exposure to environmental tobacco smoke, final report. September 1997.

17 Hecht SS. Carcinogen derived biomarkers: applications in studies of human exposure to secondhand tobacco smoke. Tobacco Control 2004; 13(suppl I):i48-56.

18 Samet JM. Adverse effects of smoke exposure on the upper airway. Tobacco Control 2004; 13(suppl I):i57-60.

19 Daynard R. How did we get here? Tobacco Control 2004;13(suppl I):i3. 